\title{
Historical tsunami database for France and its overseas territories
}

\author{
J. Lambert and M. Terrier \\ BRGM, 3 avenue Claude Guillemin, BP 36009, 45060 Orléans cedex 2, France
}

Received: 7 October 2010 - Revised: 1 February 2011 - Accepted: 1 February 2011 - Published: 5 April 2011

\begin{abstract}
A search and analysis of a large number of historical documents has made it possible: (i) to discover sofar unknown tsunamis that have hit the French coasts during the last centuries, and (ii) conversely, to disprove the tsunami nature of several events referred to in recent catalogues. This information has been structured into a database and also made available as a website (www.tsunamis.fr) that is accessible in French, English and Spanish. So far 60 genuine ("true") tsunamis have been described (with their dates, causes, oceans/seas, places observed, number of waves, flood and ebb distances, run-up, and intensities) and referenced against contemporary sources. Digitized documents are accessible online. In addition, so as to avoid confusion, tsunamis revealed as "false" or "doubtful" have been compiled into a second catalogue.

Both the database and the website are updated annually corresponding to the state of knowledge, so as to take into account newly discovered historical references and the occurrence of new tsunamis on the coasts of France and many of its overseas territories: Guadeloupe, Martinique, French Guiana, New Caledonia, Réunion, and Mayotte.
\end{abstract}

\section{Introduction}

Several studies (Louat and Baldassari, 1989; Soloviev, 1990, 2000; Tinti et al., 1996, 2004; Pelinovski et al., 2002; Lander et al., 2002; O'Loughlin and Lander, 2003; Sahal et al., 2010) have shown that the coasts of France and its overseas territories have been hit by tsunamis in the past. The significance of this fact is that, in view of increasing coastal urbanization, the consequences of such events can be extremely serious. One of the preconditions for a good assessment of

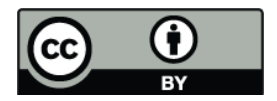

Correspondence to: J. Lambert (j.lambert@brgm.fr) the hazard, and thus the risk, and for the implementation of a prevention policy, is to acquire knowledge as accurate as possible concerning the events and their location, and then to make this knowledge available to scientists, professionals and the public.

The purpose of the work described here has been to: (i) search for documented data on the effects of the historical tsunamis that have hit France's mainland and overseas coasts, (ii) construct a computerised database, and (iii) establish a corresponding online website.

\section{Creating the tsunami database for France}

\subsection{Background}

The literature search for historical tsunamis in France is a fairly complex operation for several reasons. In the first place, the term of "tsunami" is relatively recent and only appears in European literature as of the middle of the 20th century. It is thus useless to search older literature for this term because predominantly, it has only concerned Japan and part of the Pacific. Outside of these areas, the event is referred to in French literature as "raz-de-marée" ("tidal wave"). Although seldom indexed in the archives (unlike earthquakes), the term "tidal wave" appears to be associated mainly with major meteorological events (e.g. storms, cyclones and hurricanes) which, in the present case, are outside our strict field of study. This fact radically complicated our literature search, and we were obliged to search through a very large number of documents to find traces of these tsunamis. At the same time, the strictly meteorological data found during this work has been referenced and filed.

In the second place, where historical events are concerned, notably prior to the 20th century and disregarding major disasters (e.g. Indonesia: the volcanic eruption of Krakatoa in 1883), the tsunami is a marine phenomenon whose impact

Published by Copernicus Publications on behalf of the European Geosciences Union. 
is described much more scantily in literature than the effects of earthquakes. Thus we noted during our research that the earthquake effects of a given tremor are described over relatively extensive areas, whereas the corresponding tsunami effects, which by their very nature are limited to the strictly coastal areas, are described only in rare accounts. This is even truer when the event is triggered far from the French coasts, e.g. for the Mediterranean with earthquakes on the North African coast (such as that on 21 May 2003 in Boumerdes, Algeria). This fact also contributes to the difficulty of trying to locate written accounts associating earthquakes and tsunami propagation before the existence of measuring instruments.

\subsection{Research and information structuring}

The basic approach used for this work is identical to that used for the study of historical seismicity in France (Vogt, 1979; Godefroy et al., 1990; Lambert et al., 1996; and the associated website on French historical seismicity, www.sisfrance. net). One of the principal phases of the work (Lambert, 2008, 2009) consisted in looking for and acquiring original contemporary handwritten or printed documents from the time of the event; i.e. "primary sources". Longer and more difficult than a simple compilation of catalogues, this approach enabled an exact reconstruction of the documentary sources and a stricter analysis and interpretation of the events. It avoids the ambiguities and confusion that one finds, even in recent publications.

The documentation obtained both in France and abroad comes from various sources, e.g.: books, scientific articles, historical articles, manuscripts, newspapers, travellers' accounts, chronicles and catalogues of earthquakes. It was at same time supplemented by researching the meteorological data relating to violent storms along the coasts of mainland France (Mediterranean, English Channel, Atlantic Ocean and North Sea) and hurricanes and cyclones recorded in the French islands of the Indian Ocean, Pacific Ocean and Caribbean. Compiled chronologically, this documentary framework enables an immediate comparison of the data essential for a critical analysis of the sources and a typological identification of the tsunamis.

Based on the collected archives, the information is then structured into a computerized database. Catagorizing an event as a "True", "Doubtful" or "False" tsunami was done during the analysis and comparison of the documentary sources. The events were thus classified into three categories. The first, termed "True" tsunamis, includes events for which the documentary description leaves no doubt about the tsunami origin of the phenomenon (e.g. ebb and flow movements of the waters and the retreat and advance of the sea). The second category includes events for which a tsunami origin is still considered as "Doubtful"; these events will remain there until further data are available to remove or confirm the doubt.
The third category stores "False" tsunamis, which mainly result from meteorological phenomena (e.g. depressions, storms or cyclones) and are frequently designated as "tidal waves" in French literature. Giving rise to greater or smaller coastal submergence, the effects associated with these meteorological phenomena have nothing in common with those associated with the specific characteristics of a tsunami.

In comparison with the scale of Iida (1984), the classification scheme used here is the following one: "True"/"definite tsunami", "Doubtful"/"questionable or probable tsunami", "False"/"very improbable or improbable tsunami".

For each event, an indication is given as to its cause. For this, as with the most sophisticated catalogues (such as Tinti et al., 2001, 2004), eight criteria were retained: seismic (earthquake), volcanic (eruption), gravitative (landslide), explosion, seiche, meteorite, meteorological and unknown.

\subsection{The website of tsunamis in France and in its overseas territories}

The website (www.tsunamis.fr) is linked to the computerized database, which comprises interconnected tables and descriptor fields and provides full syntheses of the events. Different menus give access to general information (definitions, user rights, site presentation, contacts and links) as well as to the entire catalogue (Lambert, 2008, 2009). The map on the home page (Fig. 1) has a twofold function: on one hand it enables one to locate the geographical distribution of the tsunamis listed on the site at the time of the consultation at a glance, and on the other it acts as a selection tool for the events listed in one of France's départements or overseas territories.

The "Tsunami catalogue" menu gives access to the "True" tsunami list and "False" or "Doubtful" tsunami list. The former provides access to various windows detailing the tsunami characteristics, whereas the latter only gives the date and geographical location of the event.

In the first place, the "Tsunami characteristics" tab lists the date, geographical region, cause and estimated intensity on the Sieberg-Ambraseys scale (Ambraseys, 1962) for each event.

The "List of observations" (Fig. 2) gives the localities where the tsunami was observed, with each observation being described by a series of parameters issued from original and primary documentary sources and defining the tsunami wave in the considered locality:

- Number and maximum height of waves (in metres), with an index of reliability

- Maximum height and drawback distance (in metres), with an index of reliability.

- Maximum inundation depth and inundation limit (in metres), with an index of reliability. 


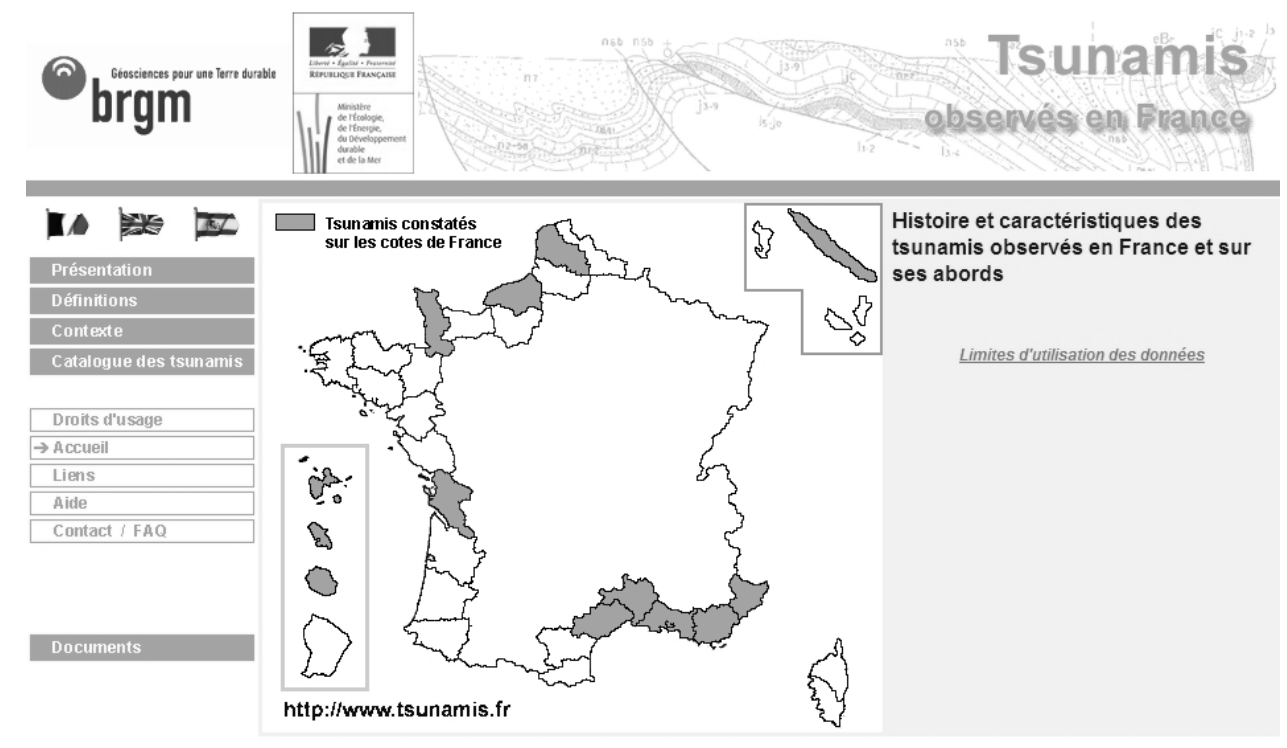

Fig. 1. Home page of the www.tsunamis.fr website.

- Run-up (measured in metres), height calculated between the reference sea level and the highest water level at the coast at the time of inundation, with an index of reliability.

- Tsunami intensity on the Sieberg-Ambraseys scale (Ambraseys, 1962), with an index of reliability.

- Longitude and latitude of the tsunami observation point (WGS 84 coordinates).

- Date: this field is filled if the date of the tsunami arrived at a location differs from the date of the event occurred (case of transoceanic tsunamis).

- Time: time when the tsunami arrived in a locality (standard time).

The reliability indices have three levels: (a) very sure data (code A), estimated from several indications obtained from the accounts of people having lived and "measured" the event; (b) fairly sure data (code B), estimated from the account of a contemporary and cross referenced with later sources; (c) dubious data (code C), or data to be checked, obtained through second-hand sources that cannot be compared with contemporary accounts. Depending on the information available, the dynamic characteristics of the tsunami wave may or may not be indicated.

The "Bibliography" tab gives access to all the referenced documentary sources describing the event, including both first-hand sources and others. In most cases, the primary sources were scanned and are accessible online (insofar as copyrights are respected).

The "Tsunami intensity map" tab (Fig. 3) provides a map of the event in dynamic mode, showing the wave intensities associated with the localities affected by the event. These localities are those indicated in the "List of observations" (Fig. 2). Interactive interrogation of a point on the map reveals the name, coordinates, intensity and estimated reliability for that locality. In addition, the localities listed in the documents as not having noted the tsunami are also indicated on the map and in the associated legend (e.g. degree 0 , wave not observed; Fig. 3). For the tsunamis of seismic origin, the position of the macroseismic epicentre is indicated if the corresponding earthquake is registered in the SisFrance database. In this case, access to the macroseismic data of the earthquake is indicated by a link.

\section{The current French catalogue}

Compiling the catalogue involved searching through hundreds of books, articles, manuscripts and newspapers. Particular attention during this documentary search was paid to obtaining archive sources from as close to the date of the events as possible. This long fastidious task allowed a critical comparison and interpretation of the origin and nature of the events. It also revealed several cases of confusion and misinterpretation (Lambert, 2009) about events that had been described as tsunamis or potential tsunamis.

\subsection{Catalogue of "True" tsunamis}

The current French catalogue indexes and describes some 60 events ("True" tsunamis) that have hit France's mainland and overseas coasts. The tsunamis are associated with 288 observation localities and 258 reliable literature references, for which 223 pages of digitized archives are accessible online. 
Table 1. "True" tsunamis referenced in the French database.

\begin{tabular}{|c|c|c|c|c|c|c|c|}
\hline Ocean-Sea & Year & Month & Day & Location & Region/Country & Intensity & Cause \\
\hline ATL & 1785 & 9 & 6 & Bay of La Rochelle & Charente-Maritime & 3.0 & $\mathrm{U}$ \\
\hline ATL & 1875 & 6 & 9 & Bay of La Rochelle & Charente-Maritime & 3.0 & $\mathrm{U}$ \\
\hline ATL & 1882 & 4 & 22 & Bay of La Rochelle & Charente-Maritime & 3.0 & $\mathrm{U}$ \\
\hline ATL & 1972 & 9 & 7 & Island of Oléron & Charente-Maritime & 2.0 & $\mathrm{E}$ \\
\hline MAN & 1725 & 7 & 13 & Bay of Flamanville & Cotentin & 2.0 & $\mathrm{U}$ \\
\hline MAN & 1810 & 9 & 19 & Bay of Boulogne-sur-Mer & Picardie & 3.0 & $\mathrm{U}$ \\
\hline MAN & 1838 & 1 & 23 & Bay of Cherbourg & Cotentin & 3.0 & $\mathrm{U}$ \\
\hline MAN & 1838 & 1 & 24 & Bay of Cherbourg & Cotentin & 3.0 & $\mathrm{U}$ \\
\hline MAN & 1838 & 1 & 25 & Bay of Cherbourg & Cotentin & 2.0 & $\mathrm{U}$ \\
\hline MAN & 1845 & 9 & 25 & Bay of Le Havre & Normandy & & $\mathrm{U}$ \\
\hline MAN & 1850 & 12 & 17 & Bay of Cherbourg & Cotentin & 3.0 & $\mathrm{U}$ \\
\hline MAN & 1858 & 6 & 5 & Normandy, Kent, Dover Strait & English Channel & 3.0 & $\mathrm{U}$ \\
\hline MED & 1564 & 7 & 20 & Bay of Nice & Côte d'Azur & 2.0 & $\mathrm{~L}$ \\
\hline MED & 1717 & 6 & 16 & Bay of Agde & Languedoc & 3.0 & $\mathrm{U}$ \\
\hline MED & 1725 & 6 & 29 & Bay of Marseilles and Cassis & Provence & 3.0 & $\mathrm{U}$ \\
\hline MED & 1812 & 6 & 27 & Bay of Marseilles & Provence & 4.0 & $\mathrm{U}$ \\
\hline MED & 1812 & 8 & 4 & Bay of Marseilles & Provence & 2.0 & $\mathrm{U}$ \\
\hline MED & 1817 & 7 & 5 & Bay of Marseilles & Provence & & $\mathrm{U}$ \\
\hline MED & 1819 & 1 & 8 & Italian Riviera & Italy & & $\mathrm{E}$ \\
\hline MED & 1829 & 7 & 8 & Bay of Marseilles & Provence & 3.0 & $\mathrm{U}$ \\
\hline MED & 1831 & 5 & 26 & Italian Riviera & Italy & 2.0 & $\mathrm{E}$ \\
\hline MED & 1841 & 7 & 14 & Bay of Marseilles & Provence & 2.0 & $\mathrm{U}$ \\
\hline MED & 1841 & 7 & 17 & Bay of Sète & Languedoc & 3.0 & $\mathrm{U}$ \\
\hline MED & 1843 & 2 & 27 & Bay of Marseilles & Provence & 3.0 & $\mathrm{U}$ \\
\hline MED & 1860 & 9 & 3 & Bay of Marseilles & Provence & & $\mathrm{U}$ \\
\hline MED & 1887 & 2 & 23 & Italian Riviera & Italy & 3.0 & $\mathrm{E}$ \\
\hline MED & 1890 & 8 & 20 & Bay of Le Grau-du-Roi & Languedoc & 3.0 & $\mathrm{U}$ \\
\hline MED & 1892 & 8 & 11 & Bay of Toulon, La Seyne & Provence & & $\mathrm{U}$ \\
\hline MED & 1897 & 6 & 30 & Bay of Six-Fours and Barcelona & Provence, Catalonia & 3.0 & $\mathrm{U}$ \\
\hline MED & 1899 & 7 & 24 & Bay of Marseilles & Provence & 2.0 & $\mathrm{U}$ \\
\hline MED & 1909 & 6 & 15 & Bay of Marseilles and Toulon & Provence & 2.0 & $\mathrm{U}$ \\
\hline MED & 1979 & 10 & 16 & Bay of Nice & Côte d'Azur & 3.0 & $\mathrm{~L}$ \\
\hline MED & 2003 & 5 & 21 & Boumerdès & Algeria & 3.0 & $\mathrm{E}$ \\
\hline MED & 2004 & 8 & 24 & Bay of Marseilles & Provence & 2.0 & $\mathrm{~L}$ \\
\hline CAR & 1755 & 11 & 1 & "Lisbonne Earthquake" & Lesser Antilles & 6.0 & $\mathrm{E}$ \\
\hline CAR & 1767 & 4 & 24 & Barbados & Lesser Antilles & 4.0 & $\mathrm{E}$ \\
\hline CAR & 1843 & 2 & 8 & North-East Guadeloupe & Lesser Antilles & 2.0 & $\mathrm{E}$ \\
\hline CAR & 1867 & 11 & 18 & Virgin Islands (St-Thomas) & Lesser Antilles & 4.0 & $\mathrm{E}$ \\
\hline CAR & 1902 & 5 & 5 & Mount Pelée & Martinique & 3.0 & V \\
\hline CAR & 1902 & 5 & 8 & Mount Pelée & Martinique & 4.0 & V \\
\hline CAR & 1902 & 5 & 20 & Mount Pelée & Martinique & 4.0 & V \\
\hline CAR & 1902 & 8 & 30 & Mount Pelée & Martinique & 3.0 & $\mathrm{~V}$ \\
\hline CAR & 1969 & 12 & 25 & Dominica & Lesser Antilles & 2.0 & $\mathrm{E}$ \\
\hline CAR & 1985 & 3 & 16 & Redonda & Lesser Antilles & 1.0 & $\mathrm{E}$ \\
\hline CAR & 1997 & 12 & 26 & Soufriere Hills (Montserrat) & Lesser Antilles & 4.0 & $\mathrm{~L}$ \\
\hline CAR & 2003 & 7 & 13 & Soufriere Hills (Montserrat) & Lesser Antilles & 2.0 & $\mathrm{~V}$ \\
\hline CAR & 2004 & 11 & 21 & Les Saintes (Guadeloupe) & Guadeloupe & 3.0 & $\mathrm{E}$ \\
\hline CAR & 2006 & 5 & 20 & Soufriere Hills (Montserrat) & Lesser Antilles & & $\mathrm{V}$ \\
\hline IND & 1883 & 8 & 27 & Krakatoa (Sunda Strait) & Indonesia & 6.0 & $\mathrm{~V}$ \\
\hline IND & 1945 & 11 & 27 & Makran Coast & Pakistan & 5.0 & $\mathrm{E}$ \\
\hline IND & 1983 & 11 & 30 & Diego Garcia Island & Chagos Archipelago & 4.0 & $\mathrm{E}$ \\
\hline IND & 2004 & 12 & 26 & Andaman (Sumatra) & Indonesia & 6.0 & $\mathrm{E}$ \\
\hline IND & 2007 & 9 & 12 & Bengkulu (Sumatra) & Indonesia & 4.0 & $\mathrm{E}$ \\
\hline PAC & 1875 & 3 & 28 & New-Caledonia, Vanuatu & New-Hebrides Archipelago & 6.0 & $\mathrm{E}$ \\
\hline PAC & 1931 & 10 & 3 & San Cristobal Island & Solomon Archipelago & 6.0 & $\mathrm{E}$ \\
\hline PAC & 1934 & 7 & 18 & Santa Cruz Island (Vanikoro) & Solomon Archipelago & & $\mathrm{E}$ \\
\hline PAC & 1934 & 7 & 21 & Santa Cruz Island (Nendo) & Solomon Archipelago & & $\mathrm{E}$ \\
\hline PAC & 1977 & 6 & 22 & South Tonga & Tonga Archipelago & & $\mathrm{E}$ \\
\hline PAC & 1998 & 3 & 25 & North Antartic earthquake & South Pacific Ocean & & $\mathrm{E}$ \\
\hline PAC & 2007 & 4 & 1 & Guadalcanal Island & Solomon Archipelago & 5.0 & $\mathrm{E}$ \\
\hline
\end{tabular}

Ocean/Sea column: MED = Mediterranean Sea; $\mathrm{CAR}=$ Caribbean Sea; $\mathrm{MAN}=$ English Channel; ATL = Atlantic Ocean; IND = Indian Ocean; PAC = Pacific Ocean. Cause of event column: $\mathrm{E}=$ earthquake $; \mathrm{L}=$ landslide $; \mathrm{V}=$ volcano $; \mathrm{U}=$ Unknown $; \mathrm{M}=$ Meteorological 


\begin{tabular}{|c|c|c|c|c|c|c|c|c|c|c|c|c|c|c|c|c|c|c|c|c|}
\hline & & & & & & & & & & 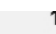 & & & & & & & & & & \\
\hline \multirow{2}{*}{ Localité } & \multirow{2}{*}{$\begin{array}{c}\text { Dept } \\
\text { Pays }\end{array}$} & \multicolumn{3}{|c|}{ Vague } & \multicolumn{4}{|c|}{ Retrait } & \multicolumn{4}{|c|}{ Inondation } & \multicolumn{2}{|c|}{ Runup } & \multicolumn{2}{|c|}{$\begin{array}{l}\text { Intensité de } \\
\text { Londe }\end{array}$} & \multirow{2}{*}{ 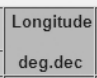 } & \multirow{2}{*}{\begin{tabular}{|l|} 
Latitude \\
deg.dec
\end{tabular}} & \multirow{2}{*}{ Date } & \multirow{2}{*}{ Heure } \\
\hline & & $\mathrm{Nb}$ & Haut. & \begin{tabular}{|l|} 
Fiab. \\
\end{tabular} & Haut. & Fiab. & Dist. & Fiab. & Haut. & Fiab. & \begin{tabular}{|l|} 
Prof. \\
\end{tabular} & Fiab. & Haut & Fiab & Int & & & & & \\
\hline ALASSIO & litalie & $\frac{1}{3}$ & & & $1 \mathrm{~m}$ & co. & $30 \mathrm{~m}$ & $c$ & $1 \mathrm{~m}$ & c & & & & & 3 & $c$ & \begin{tabular}{|l|l|l} 
& 9.172104 \\
\end{tabular} & 4 & & \\
\hline ANDORA & litalis & & & & $1 \mathrm{~m}$ & $c$ & & & $1 \mathrm{~m}$ & $c$ & & & & & 3 & $c$ & 8.169059 & 43.9695 & & \\
\hline ANTIBES & 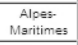 & & & & $1.5 \mathrm{~m}$ & c & & & $1 \mathrm{~m}$ & $\circ$ & & & & & 3 & c & 7.129091 & 43,582098 & & \\
\hline CANNES & $\begin{array}{c}\text { Alpes- } \\
\text { Marritimes }\end{array}$ & & & & $1 \mathrm{~m}$ & $c$ & & & $1 \mathrm{~m}$ & c & & & & & 2 & B & 7.009374 & 43,547998 & & \\
\hline \begin{tabular}{|l|} 
DIANO \\
MARINA
\end{tabular} & Hitalis & & & & $1 \mathrm{~m}$ & B & & & $1 \mathrm{~m}$ & B & & & & & 3 & c & 8.079682 & \begin{tabular}{|l|}
43,89782 \\
\end{tabular} & & \\
\hline GENOVA & litalis & & & & $0.2 \mathrm{~m}$ & $c$ & $25 \mathrm{~m}$ & $c$ & & & & & & & 2 & 8 & 8.947204 & 44,396179 & & \\
\hline MARSEILLE & 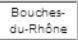 & & & & & & & & & & & & & & 0 & A & 5.354443 & \begin{tabular}{|l|l|}
43.27828 \\
\end{tabular} & & \\
\hline MENTON & \begin{tabular}{l|} 
Aloes-s \\
Martimes
\end{tabular} & & & & $0.85 \mathrm{~m}$ & c & & & & & $2.5 \mathrm{~m}$ & c & & & 2 & B & 7.508372 & 43,778351 & & \\
\hline MONACO & $\begin{array}{l}\text { Monase } \\
\text { (principastes) }\end{array}$ & & & & & & $0.8 \mathrm{~m}$ & c & & & & & & & 2 & c & 7.42198 & 43.73542 & & \\
\hline NICE & \begin{tabular}{l|} 
Alpess- \\
Martitimes
\end{tabular} & 2 & $0.65 \mathrm{~m}$ & B & & & & & & & & & & & 2 & c & 7.265015 & 43,694404 & & $\begin{array}{l}\text { entre } 6 \mathrm{homin} \\
\text { et } 6 \mathrm{~h} 8 \mathrm{~min}\end{array}$ \\
\hline ONEGLLA & Itslie & & & & $1 \mathrm{~m}$ & c & $4 m$ & $c$ & $1 \mathrm{~m}$ & c & & & & & 3 & $c$ & 8.050638 & 43.894233 & & \\
\hline 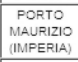 & t:alie & & & & $1 \mathrm{~m}$ & B & & & $1 \mathrm{~m}$ & c & & & & & 3 & c & 8.039 & 43,882 & & \\
\hline $\begin{array}{l}\text { SAINT. } \\
\text { JEANCA. } \\
\text { FERRAT }\end{array}$ & $\begin{array}{c}\text { Alpes- } \\
\text { Martimes }\end{array}$ & & & & & & $100 \mathrm{~m}$ & $c$ & & & & & & & 2 & c & 7.333848 & \begin{tabular}{|l|l|}
43,692227 \\
\end{tabular} & & \\
\hline SAN REMO & Hasilis & & & & $1 \mathrm{~m}$ & $c$ & & & $1 \mathrm{~m}$ & $c$ & & & & & 3 & 8 & 7,777789 & 44,817867 & & \\
\hline SAVONA & lisalie & & & & & & & & & & & & & & & A & 8.449218 & 44,282198 & & \\
\hline
\end{tabular}

Fig. 2. "List of observations" window: localities and parameters of the waves of the 23 February 1887 tsunami in the Mediterranean.
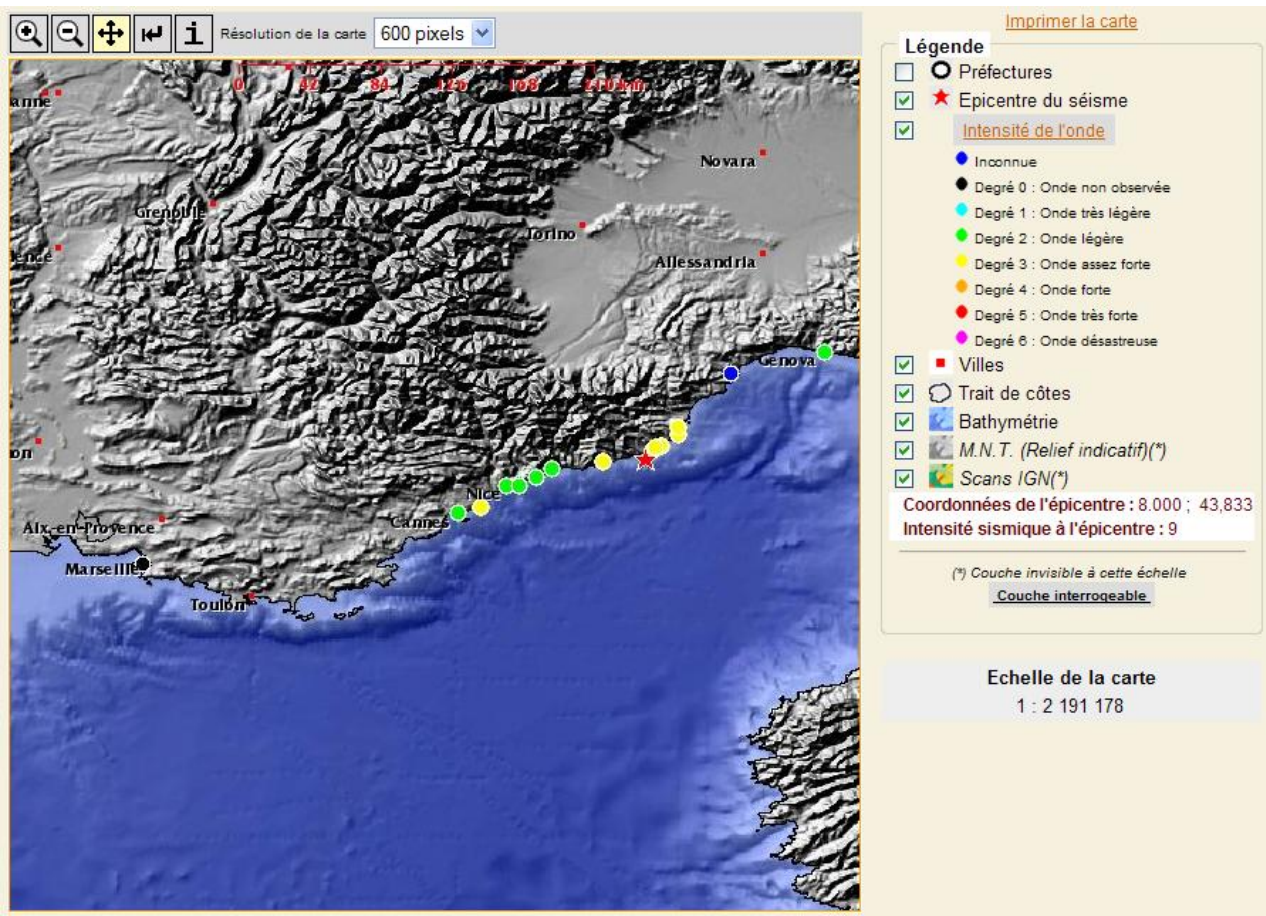

Fig. 3. "Tsunami intensity map" window: intensities of the 23 February 1887 tsunami in the Mediterranean.

In 2009, the French catalogue of tsunamis was built up as follows (Table 1):

\section{(a) Tsunamis on France's Atlantic coast}

The 1785, 1875 and 1882 tsunamis noted in La Rochelle on the Atlantic front (near Île de Ré, in Charente Maritime) are of unknown origin. Comparison of the documentary sources showed that the origin of these tsunamis did not coincide with local earthquakes. The sudden rise and fall of the water noted in the town's port was in no way similar to a tidal event.

\section{(b) Tsunamis on France's English Channel coast}

The tsunamis affecting the French coasts of the English Channel are all of unknown origin. In each case, the noted effects correspond to relatively abrupt rises and falls of the 
sea without it being possible to assign them to a seismic origin, not even a remote one.

\section{(c) Tsunamis on France's Mediterranean coast}

The origins of most of the tsunamis observed on France's Mediterranean coast are unknown. It is assumed, based on the descriptions and accounts obtained from contemporary sources, that the origin of these events could be gravitational (e.g. submarine slides) rather than tidal. Some submarine slides are in fact well identified, like that of 1979 at Nice or that of 1564 at Antibes and Villefranche-sur-Mer, this last one having been triggered by an earthquake whose epicentre (Intensity VIII MSK according to SisFrance) was located $40 \mathrm{~km}$ inland. Other tsunamis on the Mediterranean coast are of unquestionable seismic origin, like the 1887 earthquake felt extensively on the Côte d'Azur or those of 1819 and 1831 apparently limited to the proximity of the French coast (San Remo). Several tsunamis are also referenced on the coast around Marseilles, including that of 27 May 1812 with an estimated intensity of 4, which is reported in several contemporary accounts not least of which is the report by L'Hermit (1812).

\section{(d) Tsunamis affecting France's Caribbean territory (Guadeloupe, Martinique)}

The catalogued events for the Caribbean only concern the tsunamis that have been recorded at Guadeloupe and Martinique. It is obvious that many other events have taken place without it being known whether or not they reached the coasts of these two islands. It is equally obvious that the literature is scattered with descriptions of the effects of hurricanes and cyclones accompanied by "tidal waves". Not being tsunamis in the strict sense of the term, many of these events, after analysis, are included in the list of "False" tsunamis.

Save for the 1902 volcanic eruption of Mount Pelée on Martinique and the 2003-2004 eruptions on the island of Montserrat, the tsunamis of the West Indies indexed in the French catalogue are mainly associated with regional seismic activity.

An exception, however, is the tsunami caused by the earthquake known as the "Lisbon earthquake" of 1 November 1755 and whose transoceanic waves reached as far as the Leeward Islands. For this event, our research led us to original correspondence recounting the effects of this tsunami in Guadeloupe and Martinique. In particular, analysing the letters written by eyewitnesses provided us with a better assessment of the effects of the transoceanic waves at Trinite (Martinique). This is specifically the case of the "Diary of an inhabitant of Sainte-Marie, 1745-1765" (Ballet, 1896; Cottrell, 2003) and other contemporary handwritten texts (Letté, 1756). On comparing these documents, we note that the described characteristics of the tsunami waves differ appreciably from those provided in recent work. For example, Lan- der et al. (2002) give the distance of the sea's withdrawal as " $1.6 \mathrm{~km}$ " for Martinique whereas the contemporary accounts that we found evoke at the most a distance of "200 pas" (200 paces, equivalent to $125 \mathrm{~m}$ ) for Trinité, one of the rare precise observation points for this island. Similarly, according to the work of O'Loughlin and Lander (2003) a flood height of " $4.6 \mathrm{~m}$ " is envisaged at Martinique, whereas our same accounts only give a height of " 4 pieds" ( 4 feet, equivalent to $1.30 \mathrm{~m}$ flood height) at Trinité. These differences in the distance and height assessments are important. The result was that, from our thorough analysis of the original sources, we were able to correct the assessment of these parameters when compiling the French catalogue.

For other tsunamis, such as that of 18 November 1867 (Virgin Islands earthquake), we were able to determine the characteristics of the waves hitting the coasts of Guadeloupe (Basse-Terre and Terre-de-Haut) and Martinique (Fort-deFrance) from contemporary observations (Pestre, 1868; Rey, 1881). A certain amount of original information and interpretations are thus provided and accessible on the site.

Finally, for many other historical events declared as "tidal waves" in literature, we were able, by comparing the collected documents with contemporary weather data, to assign a large number of the West Indian events to the "False" tsunamis list because of their obvious confusion with the effects of hurricanes and cyclones.

\section{(e) Tsunamis affecting France's Indian Ocean territory (Réunion, Mayotte)}

For the Indian Ocean, the tsunamis recorded in the database refer either to events recognized as having reached the coasts of Réunion and Mayotte, or to other tsunamis felt in the nearby islands (Mauritius and Rodrigues). In fact, historical earthquakes responsible for tsunamis in the Indian Ocean are much more numerous (for example, the 1833 and 1861 Sumatra earthquakes) but so far we have found no proof of their incidence on Réunion or Mayotte.

\section{(f) Tsunamis affecting New Caledonia in the Pacific Ocean}

All the tsunamis affecting New Caledonia have a seismic origin. Among the more noteworthy events, is the powerful earthquake of 28 March 1875 which triggered a tsunami characterized by a wave 12 feet $(3.85 \mathrm{~m})$ high that caused the death of 26 people at Lifou (Loyalty Islands).

Thus, for the tsunamis so far referenced on the coasts of France, 22 concern the Mediterranean, 14 the Caribbean, 8 the English Channel, 7 the Pacific Ocean, 5 the Indian Ocean and 4 the Atlantic coast. Of the 23 tsunamis of seismic origin, 18 concern France's overseas territories. The tsunamis of unknown origin mostly concern mainland France. 
Table 2. "Events described as "raz-de-marée" (tidal waves) and considered as "False" (FT) or "Doubtful"(DT) tsunamis (see Table 1 for legend). State of knowledge 2009."

\begin{tabular}{|c|c|c|c|c|c|c|c|}
\hline Year & Month & Day & Name & Region & Maritime Basin & Cause & Nature \\
\hline 1694 & 11 & 24 & Storm surge (Cassis) & Provence & MED & M & FT \\
\hline 1695 & 10 & 2 & Storm surge (Martinique) & Martinique & CAR & M & FT \\
\hline 1716 & 11 & 30 & Unusual tide (Avranches, St-Malo, Le Havre) & Brittany, Normandy & MAN & M & FT \\
\hline 1718 & 3 & 6 & Hurricane surge (Martinique, Saint-Vincent) & Antilles & CAR & M & FT \\
\hline 1747 & 9 & 30 & Hurricane surge (Martinique, Saint-Eustache) & Antilles & CAR & M & FT \\
\hline 1747 & 11 & 4 & Hurricane surge (Saint-Pierre) & Martinique & CAR & M & FT \\
\hline 1748 & 1 & 12 & Storm surge (La Trinité) & Martinique & CAR & M & FT \\
\hline 1751 & 9 & 15 & Hurricane surge (Martinique, Hispaniola) & Antilles & CAR & M & FT \\
\hline 1758 & 8 & 24 & Storm surge (Sainte-Marie) & Martinique & CAR & M & FT \\
\hline 1761 & 11 & 15 & Hurricane surge (Saint-Pierre) & Martinique & CAR & M & FT \\
\hline 1765 & 7 & 31 & Hurricane surge (Basse-Terre) & Guadeloupe & CAR & M & FT \\
\hline 1766 & 12 & 2 & Heavy sea (Dunkerque, Gravelines) & English Channel & MAN & $\mathrm{U}$ & FT \\
\hline 1767 & 1 & 2 & Heavy sea (Calais, Dunkerque) & English Channel & MAN & M & FT \\
\hline 1773 & 4 & 11 & Heavy sea (Saint-Jean-de-Luz) & Bay of Biscay & ATL & M & FT \\
\hline 1775 & 10 & 6 & Heavy sea (Nord Ajaccio) & Corsica & MED & M & FT \\
\hline 1780 & 10 & 10 & Hurricane surge (Saint-Pierre) & Martinique & CAR & M & FT \\
\hline 1783 & 3 & 4 & Storm surge (Mestras) & Bassin d'Arcachon & ATL & $\mathrm{U}$ & DT \\
\hline 1788 & 8 & 14 & Hurricane surge (Caravelle) & Martinique & CAR & M & FT \\
\hline 1798 & 12 & 17 & Storm surge (Aigues-Mortes) & Languedoc & MED & M & FT \\
\hline 1804 & 9 & & Hurricane surge? (Saint-Pierre) & Martinique & CAR & $\mathrm{U}$ & DT \\
\hline 1808 & 4 & 2 & Storm surge (Marseille) & Provence & MED & M & FT \\
\hline 1818 & 2 & 23 & Storm surge (Antibes) & Côte d'Azur & MED & M & FT \\
\hline 1821 & 9 & 13 & Unusual tide (Cherbourg) & Cotentin & MAN & $\mathrm{U}$ & DT \\
\hline 1821 & 12 & 25 & Storm surge (Marseille, Cassis, Fos) & Provence & MED & M & FT \\
\hline 1822 & 12 & 18 & Hurricane surge (Martinique) & Martinique & CAR & M & FT \\
\hline 1823 & 11 & 30 & Erroneous date (see, 1824 Saint-Pierre) & Martinique & CAR & M & FT \\
\hline 1824 & 11 & 30 & Storm surge? (Saint-Pierre) & Martinique & CAR & $\mathrm{U}$ & DT \\
\hline 1827 & 11 & 30 & Storm surge (Martinique, Guadeloupe) & Antilles & CAR & M & FT \\
\hline 1829 & 2 & 10 & Storm surge (Saint-Denis) & Reunion & IND & M & FT \\
\hline 1829 & 10 & 26 & Storm surge (Martinique) & Martinique & CAR & M & FT \\
\hline 1833 & 3 & 7 & Context of Spring tide (La Hougue) & Cotentin & MAN & M & FT \\
\hline 1836 & 12 & 25 & Storm surge (Barfleur, La Hague) & Cotentin & MAN & M & FT \\
\hline 1837 & 7 & 26 & Storm surge (Saint-Pierre) & Martinique & CAR & M & FT \\
\hline 1839 & 9 & 17 & Storm surge (la Hougue) & Cotentin & MAN & M & FT \\
\hline 1841 & 7 & 17 & Storm surge (Marseille) & Provence & MED & M & FT \\
\hline 1844 & 10 & 22 & Whirlwind (Sète) & Languedoc & MED & M & FT \\
\hline 1845 & 6 & 21 & Unusual tide (Sète) & Languedoc & MED & $\mathrm{U}$ & DT \\
\hline 1846 & 12 & 4 & Storm surge (Marseille ) & Provence & MED & $\mathrm{U}$ & FT \\
\hline 1849 & 7 & 20 & Storm surge? (Marseille) & Provence & MED & $\mathrm{U}$ & FT \\
\hline 1851 & 8 & 17 & Storm surge (Guadeloupe, Sta-Lucia) & Antilles & CAR & M & FT \\
\hline 1854 & 12 & 29 & Storm surge (Nice, Cannes) & Côte d'Azur & MED & M & FT \\
\hline 1855 & 1 & 20 & Storm surge (Nice) & Côte d'Azur & MED & M & FT \\
\hline 1862 & 11 & 24 & Storm surge (Nice, Marseille, Toulon) & Provence, Côte d'Azur & MED & M & FT \\
\hline 1867 & 7 & 29 & Storm surge (Saint-Martin, Les Saintes) & Antilles & CAR & M & FT \\
\hline 1867 & 10 & 8 & Storm surge (Fort-de-France, St-Pierre) & Martinique & CAR & M & FT \\
\hline 1876 & 12 & 20 & Storm surge (Nice, Cannes) & Côte d'Azur & MED & M & FT \\
\hline 1882 & 8 & 4 & Heavy sea? (Boulogne-sur-Mer) & English Channel & MAN & $\mathrm{U}$ & FT \\
\hline 1885 & 1 & 16 & Storm surge (Nice) & Côte d'Azur & MED & M & FT \\
\hline 1886 & 11 & 10 & Storm surge (Nice, Cannes, Antibes) & Côte d'Azur & MED & M & FT \\
\hline 1886 & 12 & 16 & Storm surge (Nice) & Côte d'Azur & MED & M & FT \\
\hline 1889 & 5 & 30 & Séisme du nord Cotentin & Cotentin, Normandy & MAN & $\mathrm{U}$ & DT \\
\hline 1892 & 12 & 24 & Storm surge (Royan, Les Sables-d'Olonne) & Charente-Maritime, Vendée & ATL & M & FT \\
\hline 1902 & 11 & 24 & Storm surge (Groix, Belle-Ile) & Brittany & ATL & M & FT \\
\hline 1904 & 2 & 2 & Storm surge (Roscoff, Le Conquet, Penmarch) & Brittany & ATL & M & FT \\
\hline 1906 & 10 & 31 & Storm surge (Toulon, Nice, Cannes, Villefranche) & Côte d'Azur & MED & M & FT \\
\hline 1909 & 6 & 11 & Storm surge (Saintes-Maries, Banyuls) & Golfe du Lion & MED & M & FT \\
\hline 1909 & 10 & 28 & Storm surge (St-Malo, Port-en-Bessin) & Brittany, Normandy & MAN & M & FT \\
\hline 1910 & 2 & 11 & Storm surge (Rochefort) & Charente-Maritime & ATL & M & FT \\
\hline 1911 & 10 & 22 & Storm surge (Le Havre) & Normandy & MAN & M & FT \\
\hline 1912 & 12 & 6 & Storm surge (Port-Saint-Louis, Saintes-Maries) & Camargue & MED & M & FT \\
\hline 1916 & 11 & 18 & Storm surge (Marseille, Nice, Menton) & Provence, Côte d'Azur & MED & M & FT \\
\hline 1919 & 1 & 5 & Storm surge (Nice, Marseille) & Côte d'Azur, Provence & MED & M & FT \\
\hline 1920 & 1 & 6 & Storm surge (Hyères, Cannes, Nice) & Côte d'Azur & MED & M & FT \\
\hline 1922 & 3 & 23 & Storm surge (Nice) & Côte d'Azur & MED & M & FT \\
\hline 1924 & 1 & 9 & Storm surge & Atlantic and Mediterranean fronts & ATL, MED & M & FT \\
\hline 1924 & 7 & 20 & Storm surge (Pointe des Galets) & Reunion & IND & M & FT \\
\hline 1925 & 3 & 3 & Storm surge (Bandol, Hyères, St-Tropez) & Côte d'Azur & MED & M & FT \\
\hline 1926 & 7 & 22 & Storm surge (Fort-de-France) & Martinique & CAR & M & FT \\
\hline 1926 & 11 & 21 & Storm surge (Marseille, Cannes) & Provence, Côte d'Azur & MED & M & FT \\
\hline 1927 & 12 & 30 & Storm surge (Martinique) & Martinique & CAR & M & FT \\
\hline 1928 & 3 & 21 & Storm surge (Barcarès, Sète, Agde, Banyuls) & Languedoc, Roussillon & MED & M & FT \\
\hline 1928 & 9 & 12 & Hurricane surge (Guadeloupe, Martinique) & Guadeloupe, Martinique & CAR & M & FT \\
\hline 1936 & 10 & 2 & Heavy sea (Belle-Ile) & Brittany & ATL & $\mathrm{U}$ & FT \\
\hline 1937 & 1 & 28 & Storm surge (Concarneau) & Brittany & ATL & M & FT \\
\hline 1940 & 11 & 17 & Storm surge (Rochefort) & Charente-Maritime & ATL & M & FT \\
\hline 1944 & 4 & 10 & Hurricane surge (Saint-Denis) & Reunion & IND & M & FT \\
\hline 1950 & 6 & 28 & Heavy sea (Gruissan, Port-la-Nouvelle) & Golfe du Lion & MED & M & DT \\
\hline 1963 & 7 & 19 & Heavy sea (Cogolin) & Provence & MED & U & DT \\
\hline
\end{tabular}




\subsection{Catalogue of "False" and "Doubtful" tsunamis}

This catalogue has been compiled so as to avoid confusion and to show that no events have been omitted; the catalogue today contains 78 events (Table 2). The list was drawn up after an assiduous search and analysis of documentation referring to "tidal waves". Most of these events were associated with particular meteorological conditions (e.g. storms, cyclones or hurricanes) and flooded coasts and beaches. For other events, the true nature is "uncertain or doubtful" in view of the insufficient amount of proof or possible crosschecks.

\subsubsection{A few examples in France}

The catalogue of Ligurian earthquakes by the Italian Mercalli (1897) mentions a "tidal wave" at Nice (Alps Maritimes) on 23 December 1876. Up until now, this event has been interpreted as a probable tsunami (Pelinovski et al., 2002). However a study of the contemporary local press (Le Phare du Littoral, 1876) indicated a violent storm (tidal wave) from 20 to 23 December 1876, not only at Nice but also at Cannes. It is thus a "False" tsunami.

Another similar case is an earthquake that occurred on the Italian Riviera on 29 December 1854 and that was felt extensively on the Côte d'Azur. Its maximum of intensity was in Italy along the coast between Bussana, Bordighera and Oneglia (intensity VII-VIII MSK). According to the documentation contained in the SisFrance database, no reference to an unspecified tsunami has been located to date, even in Italian sources. Pelinovski et al. (2002) however, mention a tsunami at Nice. But the survey carried out by Pentland (1855) notes that the fishermen observed no variation in sea level at the time of the earthquake. Nor is anything mentioned in the Nice press (L'Avenir de Nice, 1854) - only this sentence in connection with the effects of the earthquake: "Les maisons se balançaient comme des roseaux; les personnes couchées se croyaient dans une barque agitée par les vagues... (the houses swayed like reeds; people lying down felt as if they were in a boat agitated by the waves... )". Nothing here indicates a tsunami. As for the meteorological conditions of the day, the same newspaper informs us that the sea was very rough between Toulon and Menton at the time of the tremor. The report of ships being tossed about in all directions, dragging their anchors, particularly in Cannes, is confirmed by another newspaper (Le Mémorial d'Aix, 1855). Until proved otherwise, and under these conditions, the suggested occurrence of a tsunami at Nice appears erroneous.

Another example occurred on 2 April 1808, for which the SisFrance database lists a major earthquake whose epicentre is located in the Piedmont area of Pinerolo, in the heart of the Alps (intensity VIII MSK). This event was felt weakly in Marseilles (intensity IV MSK). However, according to Soloviev (1990) and Pelinovski et al. (2002), a questionable tsunami is suggested at Marseilles some $470 \mathrm{~km}$ from the epicentre. Our research indicates that the town's meteorological records (Sarrazin, 1808) dated the same day as the earthquake state that "la mer a éprouvé trois flux et reflux, d'environ 6 pouces d'élévation $[18 \mathrm{~cm}]$, au dessus de son niveau, dans le canal de l'arsenal (the sea experienced three flow and ebb tides, rising some 6 inches $[18 \mathrm{~cm}]$ above its level, in the dockyard channel)". The writer added that there was, at this moment, "un fort vent de nord-ouest grand frais (a strong near gale northwesterly wind)" accompanied by a "abaissement subit du baromètre (2 lignes) (sudden fall in the barometer (2 lines))". According to the Beaufort scale measuring wind intensity, near gale corresponds to a Force 7 wind (on the scale of 12) accompanied by breaking waves. Under these conditions, the water movements noted in the channel of the port of Marseilles would be due to a meteorological cause rather than a seismic one. This event is thus classified under "False" tsunamis. Also, some other tsunamis that Pelinovski et al. (2002) say were caused by earthquakes do not appear in the SisFrance historical seismicity database. For example, on 4 December 1846, the tidal wave they mention in Marseilles was caused by strong winds and not by an earthquake (Journal des Débats, 1846), and the tsunami they record as occurring at Marseilles after the 14 August 1846 Tuscany earthquake can be considered as erroneous data, since no indication of this kind is found in the French and Italian sources.

\subsubsection{Other examples in the West Indies}

O'Loughlin and Lander (2003) report that a tsunami hit the Caribbean islands, notably Martinique and Hispaniola, on 15 September 1751. However, according to original contemporary accounts (more than 15 sources - press and local statements), a violent storm on the same day caused significant damage in Martinique, Guadeloupe, part of Jamaica and Santo Domingo. This event must thus be attributed to a hurricane rather than a tsunami.

O'Loughlin and Lander (2003) also report that on 26 July 1837, Martinique was affected by "several shocks (of an earthquake) accompanied by a terrible "raz de marée" ("tidal wave") during a dreadful hurricane"; remarks taken from a catalogue of earthquakes published by Mallet (1853). In fact, according our research and analysis, original contemporary French sources (Journal des Débats, 1837; Moniteur Universel 1837 quoting le Courrier de la Martinique) tell of the effects of a destructive hurricane in Barbados, Martinique, Tortola and Saint Thomas. There is no question of a tsunami.

\section{Conclusions}

The few examples given above show that without thorough research and detailed data comparisons, it is often difficult to make a critical analysis of a wave described by its 
extraordinary or unusual character. This approach, when working from contemporary documents, often enables one to shed light and resolve questions or ambiguities concerning such or such event listed by other reports as a "true" tsunami or as a sea-level oscillation of unknown origin.

The catalogue of tsunamis that have impinged on French territory is already a tool to raise public awareness of the risk of tsunamis hitting France's coasts, and this along with the discovery, for example, of several hitherto unknown historical tsunamis in certain coastal areas (such as the coasts of Marseilles and Perpignan in the south of France) is a benefit of this approach. In addition, the catalogue provides reference material for validating digital simulations of historical events (Pedreros et al., 2007; Terrier et al., 2007; Poisson and Pedreros, 2009), which is necessary for tsunami risk assessment studies. For the "Doubtful" tsunamis, research is still being undertaken to resolve their nature one way or the other.

So far, our search for information on tsunamis that have hit the French coasts has essentially concerned mainland France (with 34 referenced tsunamis). In the medium term, the archive research and analysis should concentrate on the overseas territories, including French Polynesia.

Where the "False" tsunamis catalogue is concerned, it contains useful documents and interpretations for creating a future database of exceptional meteorological events in France.

Acknowledgements. This work was partly funded by the "French Ministry for Ecology, Sustainable Development and Spatial Planning".

Edited by: S. Tinti

Reviewed by: two anonymous referees

\section{References}

Ambraseys, N.-N.: Data for the investigation of the seismic seawaves in the eastern Mediterranean, B. Seismol. Soc. Am., 52, 895-913, 1962.

Ballet, J.: La Guadeloupe, Renseignements sur l'histoire, la flore, la faune, la géologie, Basse-Terre, 2, 1896 (in French).

Cottrell, Ph.: Journal d'un vieil habitant de Sainte-Marie (17451765), 307 pp., Malesherbes, 2003 (in French).

Godefroy, P., Lambert, J., Levret, A., and Vaskou, P. : The French macroseismic database "SIRENE", Proceedings XXII ESC General Assembly and activity report 1988-1990, Barcelona, edited by: Roca, A. and Mayer-Rosa, D., 1, 377-382, 1990.

Iida, K.: Catalog of tsunamis in Japan and its Neighbouring Countries, Dept. of Civil Engin., Aichi Institute of Technology, Japan, 52 pp., 1984.

Journal des Débats, Paris, 15 septembre 1837 (newspaper in French).

Journal des Débats, Paris, 10 décembre 1846 (newspaper in French).

L'Hermite, Correspondance au Ministre, Manuscript, Service historique de la Défense, département Marine, Toulon, 1812 (in French).
Lambert, J.: BD Tsunamis. Inventaire historique des tsunamis en France. Année 2007, Open-file BRGM, report n ${ }^{\circ}$ BRGM-RP55993-Fr, 2008 (in French).

Lambert, J.: BD Tsunamis. Inventaire historique des tsunamis en France. Année 2009, - Open-file BRGM, report $n^{\circ}$ BRGM-RP57781-Fr, 2009 (in French).

Lambert, J., Levret, A., Cushing, M., and Durouchoux, C.: Mille ans de séismes en France, Ouest-Editions, Nantes, 80 pp., 1996 (in French).

Lander, J.-F., Whiteside, L.-S., and Lockridge, P.-A.: A brief history of tsunamis in the Caribbean Sea, Science of Tsunamis Hazards, 20, 57-94, 2002.

L'Avenir de Nice, Nice 30 décembre 1854 (in French).

Letté: Correspondance du Fort-Saint-Pierre de la Martinique du 5 novembre 1755, Manuscript, Académie des Sciences de Paris, reg. 75, Paris, fol.48-49, 1756 (in French).

Le Mémorial d'Aix, Aix-en-Provence, 14 janvier 1855 (newspaper in French).

Le Moniteur Universel, Paris, 16 septembre 1837 (newspaper in French).

Le Phare du Littoral, Nice, 23 décembre 1876 (newspaper in French).

Louat, R. and Baldassari, C.: Chronologie des séismes et des tsunamis ressentis dans la région Vanuatu Nouvelle-Calédonie (1729-1989). Rapports scientifiques et techniques. Sciences de la Terre, Géophysique, ORSTOM, Nouméa, n 1, 47 pp., 1989 (in French).

Mallet, R.: On the facts of earthquake phenomena. Catalogue of recorded earthquakes from 1606 B.C. to A.D. 1850, Transactions of the British Association for the Advancement of Science, London, 177 pp., 1853.

Mercalli, G.: I terremoti della Liguria e del Piemonte, 1897 (in Italian).

O'Loughlin, K.-F. and Lander, J.-F.: Carribbean tsunamis, A 500Year History from 1498-1998, Advance in Natural and Technological Hazards Research, 263 pp., 2003.

Pedreros, R., Terrier, M., and Poisson, B.: Tsunamis: Étude de cas au niveau de la côte antillaise française - Open-file BRGM report $n^{\circ}$ BRGM-RP-55795-Fr, 2007 (in French).

Pelinovski, E., Kharif, C., Riabov, I., and Francius, M.: Modelling of tsunami propagation in the vicinity of the French Coast of Mediterranean sea, Naturals Hazards, 25, 135-159, 2002.

Pentland: Observations faites à Nice, Comptes-rendus des séances de l'Académie des Sciences de Paris, 40, Paris, 197-198, 1855 (in French).

Pestre: Quelques observations météorologiques recueillies aux Saintes (Guadeloupe) en 1867, Archives de médecine navale, 9, Paris, 310-311, 1868 (in French).

Poisson, B. and Pedreros, R.: Numerical modelling of historical landslide-generated tsunamis in the French Lesser Antilles, Nat. Hazards Earth Syst. Sci., 10, 1281-1292, doi:10.5194/nhess-101281-2010, 2010.

Rey, H.: Etude de la colonie de la Martinique, Revue maritime et coloniale, 69, Paris, 280-281, 1881 (in French).

Sahal, A., Pelletier, B., Chatelier, J., Lavigne, F., and Schindelé, F.: A catalog of tsunamis in New Caledonia from 28 March 1875 to 30 september 2009, C. R. Geosci., 342, 434-447, 2010.

Sarrazin: Observation météorologique du 2 avril 1808 à Marseille, Manuscript, Académie de Marseille, 1808 (in French). 
Soloviev, S.-L.: Tsunamigenic Zones in the Mediterranean Sea, Natural Hazards, 3, 183-202, 1990.

Soloviev, S. L., Solovieva, O.-N., Go, Ch.-N., Kirn, K.-S., and Shchetnikov, N.-A.: Tsunamis in the Mediterranean Sea: 2000 B.C. - 2000 A.D. Translation from Russian to English by Gil B. Pontecorvo and Vasiiy I-Tropin, Dordrecht, 237 pp. (about 300 descriptions), 2000.

Terrier, M., Pedreros, R., and Poisson, B.: Tsunamis: Étude de cas au niveau de la côte méditerranéenne française - Open-file BRGM report n BRGM-RP-55765-Fr, 2007 (in French).
Tinti, S. and Maramai, A.: Catalog of tsunamis generated in Italy and in Côte d'Azur, France: A step towards a unified catalogue of tsunamis in Europe, Annali di Geofisica, 39, 1253-1299, 1996.

Tinti, S., Maramai, A., and Graziani, L.: A new version of the European tsunami catalogue: updating and revision, Nat. Hazards Earth Syst. Sci., 1, 255-262, doi:10.5194/nhess-1-255-2001, 2001.

Tinti, S., Maramai A., and Graziani, L.: The new catalogue of the Italian tsunamis, Natural Hazards, 33, 439-465, 2004.

Vogt, J.: Sismicité historique de la France: Problèmes de méthode, in Les tremblements de terre en France, Mémoire BRGM n ${ }^{\circ} 96$, 9-16, 1979 (in French). 